\title{
Spatially correlated phenotyping reveals K5-positive luminal progenitor cells and p63-K5/14-positive stem cell-like cells in human breast epithelium
}

\author{
Werner Boecker ${ }^{1,2} \cdot$ Laura van Horn $^{3} \cdot$ Göran Stenman $^{4} \cdot$ Christine Stürken $^{5} \cdot$ Udo Schumacher $^{5}$. \\ Thomas Loening $^{2} \cdot$ Lukas Liesenfeld $^{3} \cdot$ Eberhard Korsching $\mathbb{1}^{6} \cdot$ Doreen Gläser $^{7} \cdot$ Katharina Tiemann $^{3}$. \\ Igor Buchwalow ${ }^{3}$
}

Received: 22 April 2017 / Revised: 19 January 2018 / Accepted: 18 February 2018 / Published online: 9 May 2018

(c) The Author(s) 2018. This article is published with open access

\begin{abstract}
Understanding the mechanisms regulating human mammary epithelium requires knowledge of the cellular constituents of this tissue. Different and partially contradictory definitions and concepts describing the cellular hierarchy of mammary epithelium have been proposed, including our studies of keratins K5 and/or K14 as markers of progenitor cells. Furthermore, we and others have suggested that the p53 homolog p63 is a marker of human breast epithelial stem cells. In this investigation, we expand our previous studies by testing whether immunohistochemical staining with monospecific antikeratin antibodies in combination with an antibody against the stem cell marker p63 might help refine the different morphologic phenotypes in normal breast epithelium. We used in situ multilabel staining for p63, different keratins, the myoepithelial marker smooth muscle actin (SMA), the estrogen receptor (ER), and Ki67 to dissect and quantify the cellular components of 16 normal pre- and postmenopausal human breast epithelial tissue samples at the single-cell level. Importantly, we confirm the existence of $\mathrm{K} 5+$ only cells and suggest that they, in contrast to the current view, are key luminal precursor cells from which K8/18+ progeny cells evolve. These cells are further modified by the expression of ER and Ki67. We have also identified a population of p63+K5+ cells that are only found in nipple ducts. Based on our findings, we propose a new concept of the cellular hierarchy of human breast epithelium, including K5 luminal lineage progenitors throughout the ductal-lobular axis and $\mathrm{p} 63+\mathrm{K} 5+$ progenitors confined to the nipple ducts.
\end{abstract}

These authors contributed equally: Werner Boecker, Laura van Horn.

Electronic supplementary material The online version of this article (https://doi.org/10.1038/s41374-018-0054-3) contains supplementary material, which is available to authorized users.

Werner Boecker

boecker@me.com

$\triangle$ Igor Buchwalow

buchwalow@pathologie-hh.de

1 Gerhard-Domagk-Institute of Pathology, University of Muenster, Münster, Germany

2 Gerhard-Seifert Reference Center Breast, Oral- and Gynecopathology-Hanspath, Hamburg, Germany

3 Institute for Hematopathology, Hamburg, Germany

\section{Introduction}

Knowledge of the complexity of human adult mammary gland epithelium is a prerequisite for understanding normal physiological regeneration and to develop concepts of abnormal proliferative disease. Recent studies using cell sorting (CD49f, EpCAM), Hoechst 33342 staining, cell fate mapping experiments in transgenic mice, in vitro and

4 Department of Pathology and Genetics, Sahlgrenska Cancer Center, University of Gothenburg, Gothenburg, Sweden

5 Institute of Anatomy and Experimental Morphology, University Cancer Center, University Medical Center Hamburg Eppendorf, Hamburg, Germany

6 Institute of Bioinformatic, University of Münster, Münster, Germany

7 Institute of Pathology, Dietrich-Bonhoeffer Clinic, Neubrandenburg, Germany 
transplantation assays, multicolor immunofluorescence stainings, and molecular analyses have generated partially contradicting models of the breast epithelium [1-28] (Supplementary Figure 1). Several of these studies, have identified subpopulations of bipotent mammary cells in human and mouse breast epithelia with "stemness" features that are immunohistochemically strongly positive for basal keratins $\mathrm{K} 5$ and/or K14 [1, 6, 13]. Other studies have proposed a ductal stem cell zone characterized by the accumulation of $\mathrm{K} 14+\mathrm{K} 19+$ cells [8] or a subpopulation of ER+ cells $[29,30]$. Finally, based on molecular cell tracing experiments, a model has been proposed, postulating the existence of unipotent myoepithelial and luminal stem cells in the mouse mammary epithelium [22]. More recently, the stem cell marker p63 has been suggested as a marker of human breast epithelial stem cells [3]. This is in line with our findings, that human breast epithelium contains p $63+\mathrm{K} 5+$ cells [31].

Here we expand on our previous studies $[1,31]$ to further test the hypothesis that $\mathrm{K} 5+$ and/or p $63+\mathrm{K} 5+$ progenitors play a role in the maintenance of human breast epithelium. We quantitatively evaluated the expression of p63 and basal keratins $\mathrm{K} 5$ and $\mathrm{K} 14$ as phenotypic markers of stem-/progenitor cells in the mammary cell hierarchy. We used multicolor stainings to study the stem cell markers p63 [32$38]$, $\mathrm{K} 5$, and $\mathrm{K} 14$ [1, 39], the differentiation markers and luminal keratins $\mathrm{K} 18, \mathrm{~K} 8 / 18$, and $\mathrm{K} 19$ [1, 40-46], and the myoepithelial lineage markers smooth muscle actin (SMA) [47, 48], smooth muscle myosin heavy chain [49], calponin $[50,51]$, and CD10 [47, 52-55]. We also evaluated the functional markers estrogen receptor (ER)-alpha [5, 23, 29, 56-61] and Ki67 [62-66]. Based on our findings, we propose a modified concept of the cellular hierarchy of human breast epithelium, including $\mathrm{K} 5+$ luminal lineage progenitor cells in the ductal-lobular axis and p63+K5+ progenitor cells confined to nipple ducts.

\section{Material and methods}

\section{Case selection}

Histologically normal breast tissue samples were obtained from 16 women aged $27-80$ years ( 8 premenopausal aged $27-42$ years, and 8 postmenopausal aged $52-80$ years) who were undergoing surgery for breast carcinoma, fibroadenoma, or reduction mammoplasty, under informed patient consent. The samples were retrieved from the archives of the Department of Pathology of the University of Muenster (WB) and the Institute of Pathology of the Friedrich Bonfoeffer Clinic in Neubrandenburg. All tissues were immediately formalin-fixed and paraffin-embedded. Only grossly, histologically, and immunohistochemically normal tissues
Table 1 Primary antibodies used in this study

\begin{tabular}{|c|c|c|c|c|}
\hline Antibody & Catalog no. & Clone & Source & Dilution \\
\hline p63 & CM163C & $4 \mathrm{~A} 4$ & $\begin{array}{l}\text { Biocare } \\
\text { Medical }\end{array}$ & $1: 50$ \\
\hline K5 & $305 R-16$ & ER16014 & MEDAC & $1: 100$ \\
\hline $\mathrm{K} 5 / 6$ & M 7237 & D5/16 B4 & Dako & $1: 50$ \\
\hline K14 & Ab7800 & LL002 & AbCam & $1: 50$ \\
\hline K18-FITC & F4772-2ML & CY -90 & Sigma & $1 ; 50$ \\
\hline $\mathrm{K} 8 / 18$ & Mob189 & 5D3 & Zytomed & $1: 50$ \\
\hline K19 & MSK017 & A53-B/A2.26 & Zytomed & $1: 100$ \\
\hline ER & RM-9101 & SP1 & $\begin{array}{l}\text { Thermo } \\
\text { Fisher }\end{array}$ & $1: 50$ \\
\hline Ki67 & RM-9106 & SP6 & $\begin{array}{l}\text { Thermo } \\
\text { Fisher }\end{array}$ & $1: 100$ \\
\hline SMA & ab5694 & $\begin{array}{l}\text { Rabbit } \\
\text { polyclonal }\end{array}$ & AbCam & $1: 200$ \\
\hline Calponin & M 3556 & CALP1 & DAKO & $1: 50$ \\
\hline CD10 & $\begin{array}{l}\text { NCL-L- } \\
\text { CD10-270 }\end{array}$ & $56 \mathrm{C} 6$ & Novocastra & $1: 10$ \\
\hline SMM-HC ${ }^{\mathrm{a}}$ & MSK030 & $1 \mathrm{~A} 4$ & Zytomed & $1: 50$ \\
\hline
\end{tabular}

${ }^{\text {a }}$ Smooth muscle myosin heavy chain

were included. The samples were taken at a distance of at least $3 \mathrm{~cm}$ from the site of the tumor. Samples with any type of epithelial hyperplasia (blunt duct adenosis, columnar cell change/hyperplasia, usual ductal hyperplasia) or intraepithelial atypia (flat epithelial atypia, atypical ductal hyperplasia, ductal carcinoma in situ, lobular neoplasia), as defined by the current WHO classification of breast tumors [67], were excluded. Parity history, menstrual cycle status, use of oral contraceptives, and hormone replacement therapy were not included in this study.

\section{Bright-field microscopy}

The primary antibodies used are shown in Table 1. For bright-field microscopy, primary antibodies were detected using the Dako LSAB REAL Detection System (Naphthol phosphate/Fast Red, no. K5005; Dako Corporation, Hamburg, Germany) or AmpliStain ${ }^{\mathrm{TM}}$ Horseradish Peroxidase (HRP) conjugates (SDT GmbH, Baesweiler, Germany) according to the manufacturers' instructions [68]. The HRP label was visualized using a 3,3'-diaminobenzidine (DAB) substrate kit (Vector Laboratories, Burlingame, CA, USA).

\section{In situ multicolor staining}

Triple immunostaining was performed using antibodies against p63, basal keratins $\mathrm{K} 5$ and $\mathrm{K} 14$, luminal keratins K18-fluorescein isothiocyanate (FITC), K8/18, K19, SMA, calponin, and $\mathrm{CD} 10$, and the functional markers ER and Ki67 (compare Fig. 1). As double staining with the three 


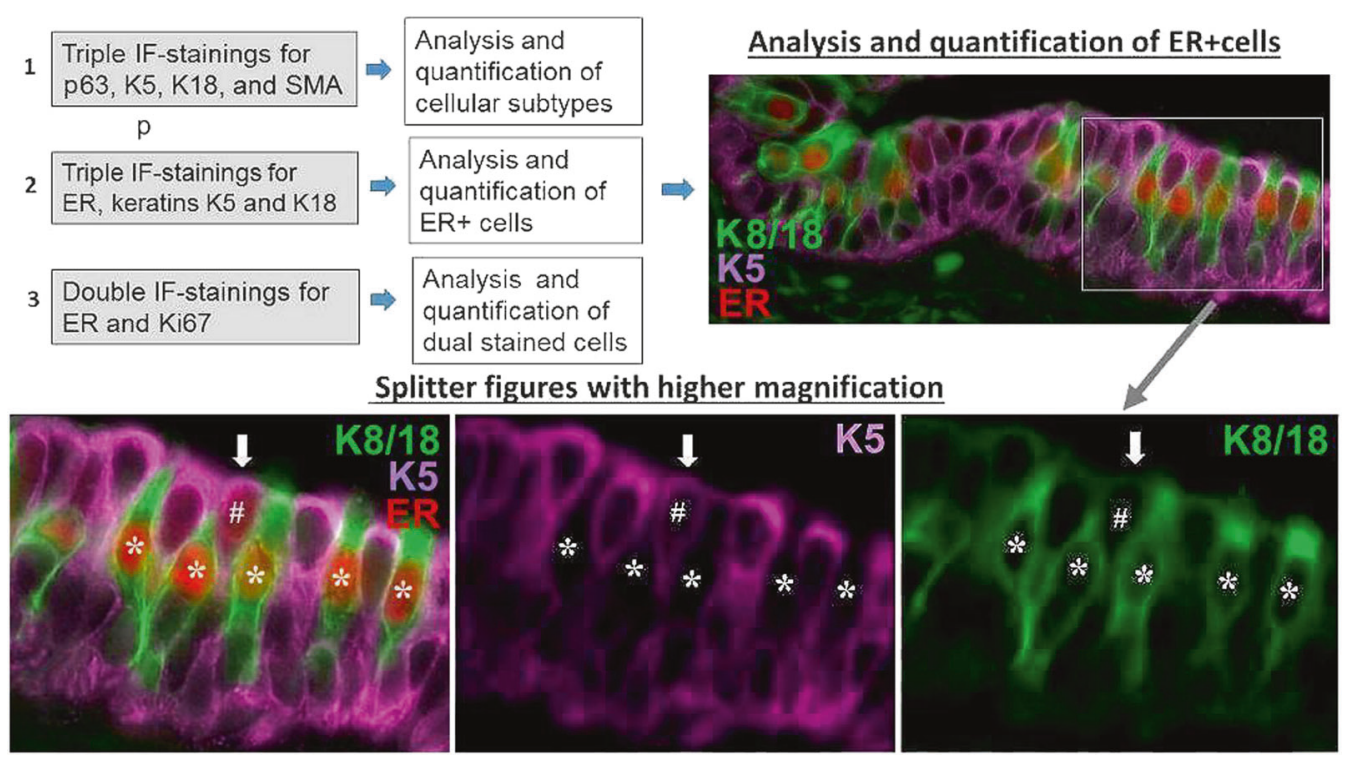

Fig. 1 Study design. Multiple immunofluorescence stainings for p63, K5, K8/18, SMA, ER, Ki67 were used to characterize the different phenotypes of cells found in normal human breast epithelium. The analysis and the quantification of the different expression patterns was

luminal keratin antibodies each showed identical results (Supplementary Figures 8-10), K8/18 was used throughout the text. Likewise, multiple immunofluorescence stainings for SMA, calponin, smooth muscle myosin heavy chain, and CD10 revealed identical results (Supplementary Figures 811); although, the staining intensity for these markers differed in single cells. SMA was used in all triple staining studies and is therefore used throughout the text. For all studies, secondary antibodies (Dianova, Hamburg, Germany, and Molecular Probes, Darmstadt, Germany) conjugated with Cy3, Alexa Fluor-488, Alexa Fluor-647, or biotin were used. For simultaneous visualization of the primary antibodies of the same $\operatorname{IgG}$ isotype, the antibodies were non-covalently labeled in vitro with a reporter molecule employing monovalent IgG Fc-specific Fab fragments [69]. The reporter molecule was either the fluorophore $\mathrm{Cy} 3$ or biotin. The latter was visualized using fluorophore-labeled streptavidin. Nuclei were counterstained with 4',6-diamidino-2-phenylindole (DAPI, $5 \mu \mathrm{g} / \mathrm{ml}$ in phosphate-buffered saline [PBS]) for $15 \mathrm{~s}$, and the sections were then mounted using VectaShield (Vector Laboratories, Burlingame, USA).

\section{Image acquisition}

Immunostained sections were examined with a Zeiss microscope (Axio Imager Z1). Images were captured with an AxioCam black and white digital microscope camera. The AxioVision image processing program (Carl Zeiss Vision, Germany) allows fluorophores to be visualized in any artificial color. For example, in some figures, we chose the yellow color for the red fluorophore $\mathrm{Cy} 3$ because the performed using merge and splitter figures at higher magnification. This picture shows a triple staining for ER, K5, and K8/18. Notice that the $\mathrm{ER}+\mathrm{K} 8 / 18+$ cells (asterisks) and the single-ER+K5+ cell (hashtag) are easily recognized

other two labels were green and red. Far-red fluorescence (Alexa 647) was also presented in different artificial colors, although usually in pink (magenta).

\section{Quantification of immunohistochemical and multicolor immunofluorescence staining}

The different p63 and keratin epithelial phenotypes and their functional features (Ki67 and ER expression) were quantified and expressed as percentages of the total number of cells counted. Photographs were randomly acquired using a highpower lens and the appropriate filter sets in succession for the visualization of DAPI, Cy5 or Alexa Fluor 647, Cy3, and FITC or Alexa Fluor 488 to assess the presence of these antigens in single-labeled cells. Positively stained cells were determined by counting cells within at least 10 fields of view per slide using a $\times 40$ objective $(700 \times 500 \mu \mathrm{m})$. Quantification of the cell content was performed using a counting program incorporated in the AxioVision software. Ten merged images per triple staining and case were taken using the splitter display of the AxioVision image processing software (Carl Zeiss Vision, Germany) to analyze and count cell by cell at higher magnification (Fig. 1).

\section{Results}

\section{Immunohistology}

Immunohistochemically, nipple ducts are characterized by a basal (myoepithelial) layer positive for p63, basal keratins 


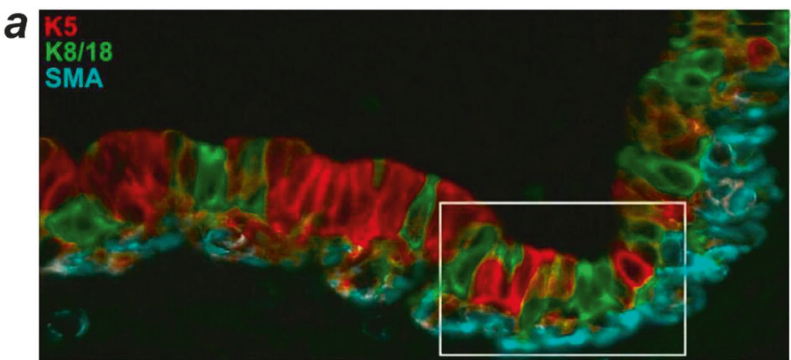

b
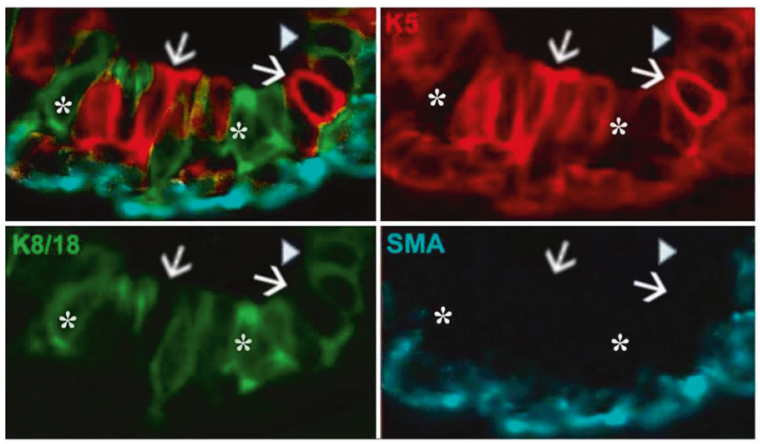

Fig. 2 Nipple duct: Triple immunofluorescence staining for K5 (red), K8/18 (green), and SMA (cyan). a Merge picture and b marge and splitter figures at higher magnification. The cells of the outer cell layer of the duct express K5 and SMA. The luminal layer contains K5positive cells (arrows), $\mathrm{K} 5+\mathrm{K} 18+$ intermediary cells (arrow head) and $\mathrm{K} 18+$ glandular cells (asterisks)

K5 (variably) and K14, and myoepithelial markers, such as SMA, calponin, and CD10. The luminal layer of the ductal epithelium showed a heterogeneous staining pattern with many luminal cells being positive for basal keratins $\mathrm{K} 5$ and/ or glandular keratins K8/18 (Supplementary Figure 2). Based on the staining of basal keratins $\mathrm{K} 5$ and luminal keratins $\mathrm{K} 8 / 18$, two types of terminal ductal-lobular units (TDLU) could be distinguished (Supplementary Figure 3): one type containing mainly or even only luminal cells expressing keratins $\mathrm{K} 8 / 18$ (mature lobule) and a second type consisting of luminal cells that, in varying numbers, co-expressed luminal keratins $\mathrm{K} 8 / 18$ and the basal keratin K5 (immature lobule).

\section{Nipple ducts}

Triple immunofluorescence staining revealed a multitude of multi-colored cells within the nipple ducts (Supplementary Figure 4). In terms of keratin expression patterns, three different cell types could be robustly distinguished in the luminal layer (Fig. 2 and Supplementary Figures 5-7): K5+K14+/cells, intermediary cells co-expressing basal keratins $\mathrm{K} 5+\mathrm{K} 14$ $+/-$ and luminal keratins $\mathrm{K} 8 / 18$, and finally $\mathrm{K} 8 / 18+$ glandular cells (Fig. 2b and Supplementary Figure 6). Similar findings were obtained when using K18-FITC or K19 instead of K8/18 antibodies (Supplementary Figures 8-11). K5+K14 $+/-$ luminal cells appeared to transform to $\mathrm{K} 8 / 18+$ cells
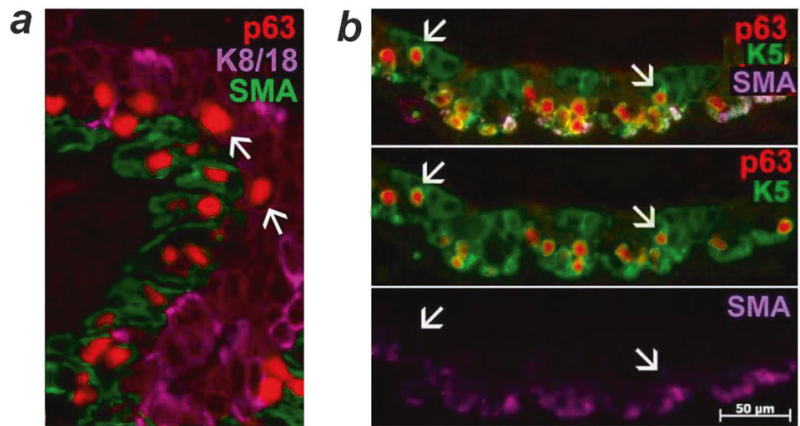

Fig. 3 Nipple duct. a Triple immunofluorescence staining for p63, K8/ 18, and SMA. p63 + cells (arrows) at the interface of the myoepithelial and luminal layer are negative not only for K8/18 but also for SMA (see also Supplementary Figure 12). b Triple staining for p63(red) and K5 (green), and SMA (pink). Notice that p63+ cells are tethered to the luminal cells (arrows) and show a transition of p63+K5+ cells to $\mathrm{K} 5+$ cells in a more luminal position

through a shift in their keratin expression from basal keratins to glandular keratins. Luminal cells expressing only K14 were rarely found (Supplementary Figure 5). Surprisingly, we found a small number of $\mathrm{p} 63+\mathrm{K} 5 / 14+$ cells at the interphase of the myoepithelial/luminal layer of the nipple ducts in all 16 cases (compare Fig. 3a, b and Supplementary Figure 12. These cells expressed neither keratins K8/18 nor the myoepithelial marker SMA. Some of these p63+/K5/14+ cells seemed to be restricted to the luminal layer with a transition to K5-only-positive cells (Fig. 3), thus showing a striking similarity to the cellular constituents of salivary gland excretory ducts (Supplementary Figure 13). The quantification of the luminal epithelium of the breast nipple ducts of pre- and postmenopausal women are shown in Tables 2 and 3 . Concerning the $\mathrm{K} 5(\mathrm{~K} 14+/-)$ cells and $\mathrm{p} 63+\mathrm{K} 5+$ progenitors in the ductal-lobular axis and the ER-expression pattern in nipple ducts and lobules, we found no differences between fibroadenoma or carcinoma bearing breasts or samples obtained from reduction mammoplasty. Importantly, quantification of a total of 10,331 cells across all cases revealed a small number of K5-only-positive cells (average $5.1 \%$ ), approximately two-thirds of $\mathrm{K} 5$ and $\mathrm{K} 8 / 18$ coexpressing intermediary cells (average 63.47\%), and onethird of K8/18-only-positive cells (average 31.4\%) (Fig. 4a; Table 2). Less than an average of $1 \%$ of the cells expressed p63 and K5/14 and lacked K8/18 and SMA (Table 2).

About one-fifth (average 20.8\%) of the cells expressed $\mathrm{ER}$, and nearly all of these co-expressed K8/18. Only a small percentage of ER+ cells co-expressed K5 (Fig. 5a, Table 3). Analyses of the expression of Ki67 and ER revealed double staining of $\mathrm{Ki} 67$ and ER in $2.3 \%$ and $10.6 \%$ of Ki67+ cells in premenopausal and postmenopausal females, respectively (Fig. 5b, Supplementary Figure 14, Table 4). 
Table 2 Quantification of triple-stained sections for K5, K8/18, and SMA in 8 premenopausal and 8 postmenopausal women (range in brackets)

\begin{tabular}{|c|c|c|c|c|c|c|}
\hline Object & $\begin{array}{l}\text { No. of } \\
\text { cases }\end{array}$ & $\begin{array}{l}\text { Total no. } \\
\text { of luminal } \\
\text { cells }\end{array}$ & $\begin{array}{l}\text { K5+K8/18-neg. } \\
\text { cells }\end{array}$ & $\begin{array}{l}\mathrm{K} 5+\mathrm{K} 8 / 18+ \\
\text { cells }\end{array}$ & $\begin{array}{l}\text { K8/18+K5-neg. } \\
\text { cells }\end{array}$ & $\begin{array}{l}\mathrm{P} 63+\mathrm{K} 5 / 14+ \\
\text { only cells }^{\mathrm{a}}\end{array}$ \\
\hline $\begin{array}{l}\text { Ducts, } \\
\text { prem. }\end{array}$ & $n=8$ & 6188 & $\begin{array}{l}278 \\
4.5 \% \\
(1.2-13.8 \%)\end{array}$ & $\begin{array}{l}4112 \\
66.5 \% \\
(31.8-86.7 \%)\end{array}$ & $\begin{array}{l}1798 \\
29.3 \% \\
(10.3-54.3 \%)\end{array}$ & $\begin{array}{l}0.92 \% * \\
(0.49-1.8 \%)\end{array}$ \\
\hline $\begin{array}{l}\text { Ducts, } \\
\text { postm. }\end{array}$ & $n=8$ & 4143 & $\begin{array}{l}251 \\
6.1 \% \\
(1.7-10.86 \%)\end{array}$ & $\begin{array}{l}2446 \\
59 \% \\
(30.5-86.5 \%)\end{array}$ & $\begin{array}{l}1446 \\
34.9 \% \\
(11.3-60.2 \%\end{array}$ & $\begin{array}{l}0.88 \% \\
(0.43-1.38 \%)\end{array}$ \\
\hline $\begin{array}{l}\text { Ducts, } \\
\text { total }\end{array}$ & $n=16$ & 10,331 & $\begin{array}{l}529 \\
5.1 \%\end{array}$ & $\begin{array}{l}6558 \\
63.47 \%\end{array}$ & $\begin{array}{l}3244 \\
31.40 \%\end{array}$ & $0.89 \%$ \\
\hline $\begin{array}{l}\text { TDLUs, } \\
\text { prem. }\end{array}$ & $n=8$ & 4864 & $\begin{array}{l}77 \\
1.06 \% \\
(0.16-3.75 \%\end{array}$ & $\begin{array}{l}1437 \\
29.5 \% \\
(6-63.4 \%)\end{array}$ & $\begin{array}{l}3350 \\
68.9 \% \\
(35.2 \%-92 \%)\end{array}$ & $\begin{array}{l}0.09 \\
(0-0.36 \%)\end{array}$ \\
\hline $\begin{array}{l}\text { TDLUs, } \\
\text { postm. }\end{array}$ & $n=6$ & 5498 & $\begin{array}{l}141 \\
2.6 \% \\
(0.53-4.7 \%)\end{array}$ & $\begin{array}{l}1767 \\
32.1 \% \\
(14.4-44.5 \%)\end{array}$ & $\begin{array}{l}3590 \\
65.3 \% \\
(54.95-84.7 \%)\end{array}$ & $\begin{array}{l}0.05 \% \\
(0-0.17 \%)\end{array}$ \\
\hline $\begin{array}{l}\text { TDLUs, } \\
\text { total }\end{array}$ & $n=16$ & 10,362 & $\begin{array}{l}218 \\
2.1 \%\end{array}$ & $\begin{array}{l}3204 \\
30.92 \%\end{array}$ & $\begin{array}{l}6940 \\
66.97 \%\end{array}$ & $0.07 \%$ \\
\hline
\end{tabular}

${ }^{\mathrm{a}} \mathrm{p} 63+\mathrm{K} 5 / 14$ positive cells were calculated on the basis of triple stainings for p63, K18, and SMA

\section{Terminal duct-lobular units (TDLUs)}

Triple immunofluorescence staining of TDLUs revealed the full set of luminal cells with $\mathrm{K} 5+\mathrm{K} 14+/-$ cells, $\mathrm{K} 5+\mathrm{K} 8 / 18$ + intermediary cells, and K8/18+ glandular cells (Fig. 6). The myoepithelial layer consisted of p63+/K5+ (variably)/ $\mathrm{K} 14+/ \mathrm{SMA}+$ cells. The quantification of TDLUs from premenopausal and postmenopausal women are shown in Tables 2 and 3. Overall, quantification of a total of 10,362 luminal lobular cells revealed that a small number of cells expressed K5 only (average $2.1 \%$ ), approximately one-third co-expressed K5 and K8/18 (average 30.92\%), and nearly two-thirds expressed only the glandular keratins K8/18 (average 66.97\%) (Fig. 4b and Table 2). In contrast to the nipple ducts, the p63+ cells in TDLUs were confined to the myoepithelial cell layer (Fig. 7a).

Analysis of the ER status revealed nearly one-third of ER + cells (average 29.4\%), including mainly ER and K18 coexpressing cells (average 28.9\%) and a minor fraction $(0.5 \%)$ of ER+K5+K18+ cells (Table 3). Quantification of Ki67 and ER double stainings revealed that 3.3 and $17.03 \%$ of Ki67+ cells co-expressed Ki67 and ER in premenopausal and postmenopausal women, respectively (Fig. 7b and Table 4).

\section{Discussion}

Here we present a modified concept of the cellular organization of normal human breast epithelium (Fig. 8) compared to that envisioned in most current concepts (Supplementary Figure 1). Importantly, we have identified a discrete population of $\mathrm{K} 5+(\mathrm{K} 14+/-)$ progenitor cells which, in contrast to the current view, are regarded as part of a larger contiguous, tightly linked cell population in the luminal layer of both nipple ducts and lobules. Glandular differentiation involves the sequential modulation of these cells with a shift from $\mathrm{K} 5+(\mathrm{K} 14+/-)$ cells via $\mathrm{K} 5+\mathrm{K} 8 / 18+$ intermediary cells to $\mathrm{K} 8 / 18+$ glandular cells, as shown in our working model in Fig. 8. Our findings are in line with the observations of Lim et al. [3] who identified a CD49f $\mathrm{f}^{\text {pos }}$ (alpha-6 integrin)/EpCAM ${ }^{\text {pos }}$ subpopulation of luminalrestricted progenitor cells characterized immunohistochemically by the expression of $\mathrm{K} 5 / 6$ (49.9\%), K8/18 (91\%), MUC1 (80\%), and ER (28\%), but lacking p63 (Fig. 9). In vitro studies, showed that these cells generated only homogeneous glandular structures. This study is notable because it emphasizes our observations that lineage identity cannot be based solely on the presence or absence of basal keratins K5 and/or K14. For example, K5+ (and/or $\mathrm{K} 14+$ ) cells co-expressing p63 and SMA clearly belong to the myoepithelial/basal lineage [70, 71], whereas K5+(K14 $+/-)$ only cells and $\mathrm{K} 5+(\mathrm{K} 14+/-) \mathrm{K} 8 / 18+$ cells, according to our observations, belong to the luminal lineage.

We have also identified a small population of $\mathrm{p} 63+\mathrm{K} 5 /$ $14+$ precursor cells residing at the interface between the myoepithelial and luminal cell layers of the human nipple duct epithelium. These cells seem to be the least differentiated cells expressing neither the luminal keratins K8/18 nor the myoepithelial marker SMA. Based on previous data, we suggest that these cells may undergo a transition from their original $\mathrm{p} 63+\mathrm{K} 5 / 14+$ precursor state to a $\mathrm{K} 5+\mathrm{K} 14$ $+/$ - luminal precursor state, and that they also may generate the p63+ SMA+ myoepithelial cells [3]. For example, 
Table 3 Quantification of triple stainings for ER, K5, and K8/18 in premenopausal and postmenopausal women (range in brackets)

\begin{tabular}{|c|c|c|c|c|c|c|}
\hline Objects & $\begin{array}{l}\text { No. of } \\
\text { cases }\end{array}$ & $\begin{array}{l}\text { Total no. of } \\
\text { luminal cells }\end{array}$ & $\mathrm{ER}+$ cells & $\begin{array}{l}\mathrm{ER}+\mathrm{K} 5+ \\
\text { cells }\end{array}$ & $\begin{array}{l}\mathrm{ER}+\mathrm{K} 5+\mathrm{K} 8 / \\
18+\text { cells }\end{array}$ & $\mathrm{ER}+\mathrm{K} 8 / 18+$ cells \\
\hline $\begin{array}{l}\text { Ducts, } \\
\text { prem. }\end{array}$ & $n=8$ & 9817 & $\begin{array}{l}1565 \\
15.94 \% \\
(11.36 \%-24.5 \%)\end{array}$ & $\begin{array}{l}3 \\
0.03 \% \\
(0-0.08 \%)\end{array}$ & $\begin{array}{l}88 \\
0.89 \% \\
(0-3.3 \%)\end{array}$ & $\begin{array}{l}1473 \\
15.00 \% \\
(10.08-21.2 \%)\end{array}$ \\
\hline $\begin{array}{l}\text { Ducts, } \\
\text { postm. }\end{array}$ & $n=5$ & 7197 & $\begin{array}{l}1978 \\
27.5 \% \\
(21.47-36.4 \%)\end{array}$ & $\begin{array}{l}4 \\
0.06 \% \\
(0-0.2 \%)\end{array}$ & $\begin{array}{l}61 \\
0.85 \% \\
(0.4-2.56 \%\end{array}$ & $\begin{array}{l}1913 \\
26.6 \% \\
(19.92-33.7 \%)\end{array}$ \\
\hline Ducts, total & $n=13$ & 17,014 & $\begin{array}{l}3543 \\
20.8 \%\end{array}$ & $\begin{array}{l}7 \\
0.04 \%\end{array}$ & $\begin{array}{l}149 \\
0.87 \%\end{array}$ & $\begin{array}{l}3386 \\
19.9 \%\end{array}$ \\
\hline $\begin{array}{l}\text { TDLUs, } \\
\text { prem. }\end{array}$ & $n=8$ & 6518 & $\begin{array}{l}1314 \\
19.91 \% \\
(12.91-29.51 \%)\end{array}$ & 0 & $\begin{array}{l}13 \\
0.2 \% \\
(0-0.44 \%)\end{array}$ & $\begin{array}{l}1301 \\
19.71 \% \\
12.47-29.32 \%)\end{array}$ \\
\hline $\begin{array}{l}\text { TDLUs, } \\
\text { postm. }\end{array}$ & $n=5$ & 6651 & $\begin{array}{l}2559 \\
38.4 \% \\
(29.45-46.74 \%)\end{array}$ & 0 & $\begin{array}{l}53 \\
0.79 \% \\
(0.12-18 \%)\end{array}$ & $\begin{array}{l}2506 \\
37.67 \% \\
(24.9 \%-37.1 \%)\end{array}$ \\
\hline $\begin{array}{l}\text { TDLUs, } \\
\text { total }\end{array}$ & $n=13$ & 13,169 & $\begin{array}{l}3873 \\
29.4 \%\end{array}$ & 0 & $\begin{array}{l}66 \\
0.5 \%\end{array}$ & $\begin{array}{l}3807 \\
28.9 \%\end{array}$ \\
\hline
\end{tabular}

a
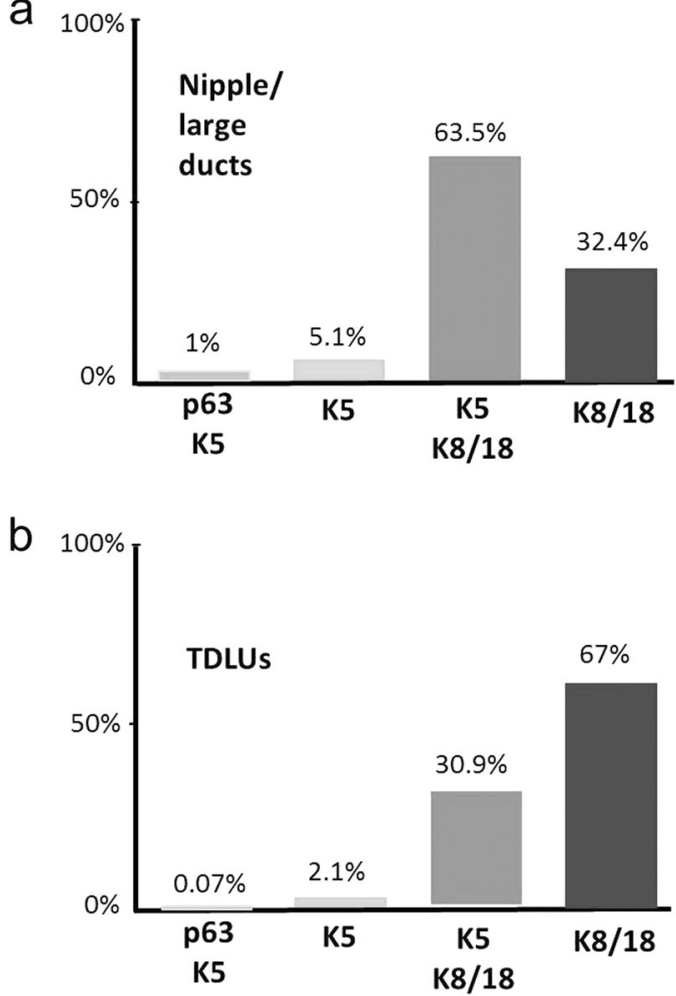

Fig. 4 Diagrams showing the average frequency of different cells types in normal breast epithelium of ducts (a) and lobules (b)

Lim et al. observed a CD49 $\mathrm{f}^{\text {high }}$ EpCAM $^{\text {neg }}$ subpopulation of human breast epithelial progenitors characterized immunohistochemically by the expression of p63 (76\%), K14 (70\%), and K5/6 (52\%), and lacking K8/18 (2.3\%) and ER $(0.2 \%)$. In transplantation assays, only this subpopulation of human epithelial breast cells showed bilinear differentiation potential [3] (cf. Fig. 8). Furthermore, the view a

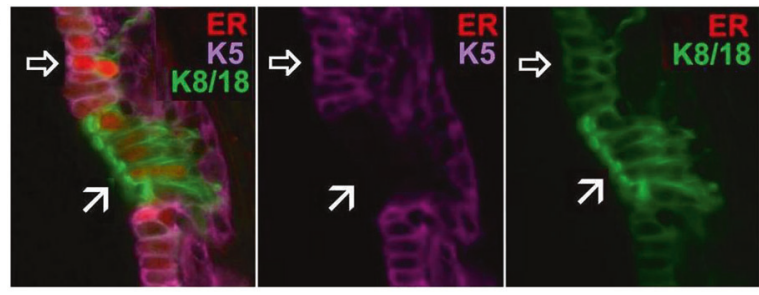

b

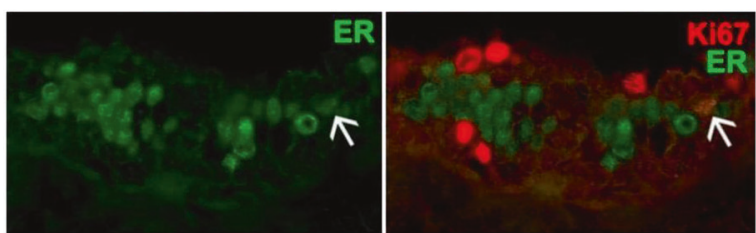

Fig. 5 Nipple duct. a Triple immunofluorescence staining for ER (red), K5 (pink), and K8/18 (green). The picture shows that ER is here is expressed in $\mathrm{K} 18+$ luminal cells (arrows) and in $\mathrm{K} 5+\mathrm{K} 8 / 18+$ intermediary cells (open arrows). b Double staining for Ki67 and ER, which shows mutually exclusive ER or Ki67-positivity with only one exception (arrow)

Table 4 Quantification of double stainings for Ki67 and ER

\begin{tabular}{llll}
\hline Object & Ki67 (total) & Ki67+ only & Ki67+/ER+ \\
\hline $\begin{array}{l}\text { Ducts, premenopausal } \\
(n=6)\end{array}$ & 260 & $\begin{array}{l}254 \\
(97.69 \%)\end{array}$ & 6 \\
$\begin{array}{l}\text { Ducts, postmenopausal } \\
(n=5)\end{array}$ & 302 & 270 & 32 \\
$\begin{array}{l}\text { Ducts, total } \\
(n=11)\end{array}$ & 562 & $(89.4 \%)$ & $(10.6 \%)$ \\
$\begin{array}{l}\text { TDLUs, premenopausal } \\
(n=6)\end{array}$ & 302 & 524 & 38 \\
$\begin{array}{l}\text { TDLUs, postmenopausal } \\
(n=5)\end{array}$ & 270 & $(93.24 \%)$ & $(6.76 \%)$ \\
$\begin{array}{l}\text { TDLUs, total } \\
(n=11)\end{array}$ & 592 & 244 & 10 \\
\hline
\end{tabular}


a

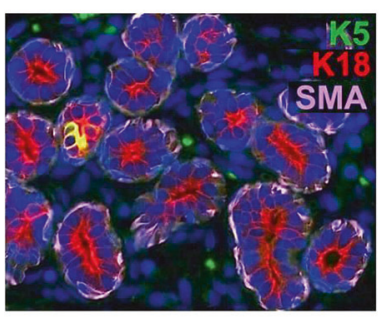

C

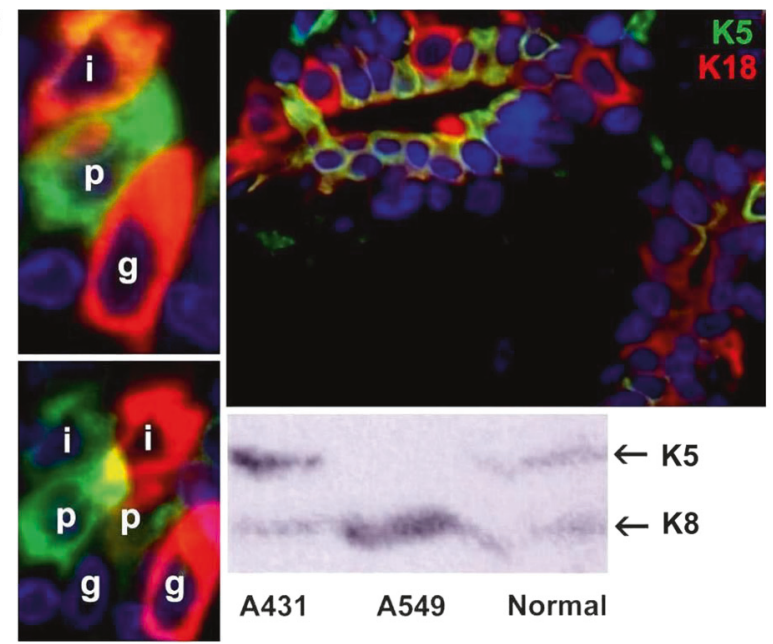

Fig. 6 Breast lobules. a, b Triple stainings for K5, K18, and SMA. a This picture highlights a mature lobule with expression of only K8/18 in nearly all acinar cells. Only one acinus contains cells with a hybrid color, indicating the co-expression of $\mathrm{K} 5$ and K8/18. The myoepithelial cells stain for SMA. b This lobule contains many luminal cells co-expressing the basal keratin $\mathrm{K} 5$ and the luminal keratin $\mathrm{K} 8 / 18$, indicating intermediary cells. c Double staining for K5 (green) and K18 (red) showing the heterogeneity of luminal cells with a K5+ luminal progenitor (p), $\mathrm{K} 5+\mathrm{K} 8 / 18+$ intermediary cell (i) and a $\mathrm{K} 8 / 18$ + glandular cell $(\mathrm{g})$. The western blotting immunoreaction with $\mathrm{K} 5$ and K18 antibodies of total cellular proteins from micro-dissected lobular cells and of two well-known cell lines (A413 and A449) shows, as expected, 2 bands in normal epithelial cells (c from ref. [46])

that p63 may play a role in breast epithelium is supported by recent studies showing that Notch signaling downregulates p63 expression prior to luminal lineage commitment [72]. Similarly, Notch inactivation in mouse mammary glands leads to accumulation of immature p63+K5+ cells (even in luminal position) and K14+K18+ cells [73]. Finally, the crucial role of p63 in the maintenance of epithelium has also been demonstrated at several other anatomical sites, including, for example, the thymus, epidermis, upper airways, and prostate [36, 37, 74-80].

In the present study, the average ER expression level of lobular cells was higher than that in nipple ducts. In agreement with the literature, the level of ER expression in the lobular epithelium of postmenopausal women (38.4\%) was much higher than in premenopausal women (19.9\%). Among the different luminal phenotypes, we found ERalpha expression in $\mathrm{K} 8 / 18+$ differentiated cells, whereas
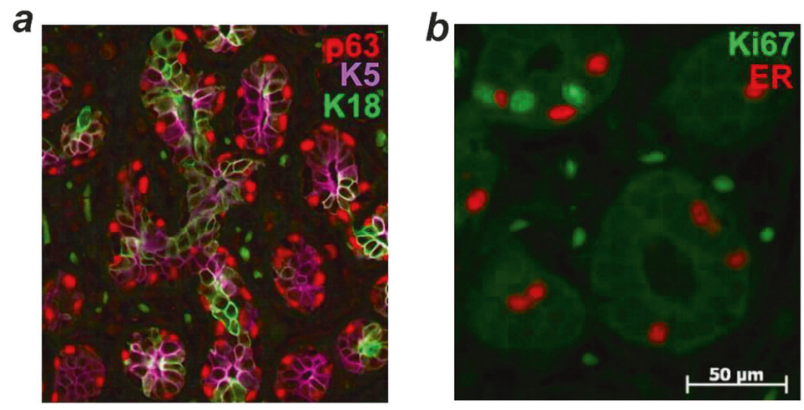

Fig. 7 Breast lobule a Triple immunofluorescence staining for $\mathrm{p} 63$, $\mathrm{K} 5$, and $\mathrm{K} 8 / 18$. Notice that p63-positive cells reside only in the basal position. b Double staining for ER and Ki67 shows mutually exclusive ER or Ki67-positivity

only a limited number of $\mathrm{K} 5+\mathrm{K} 8 / 18+$ progenitor cells showed ER-positivity. The significance of ER expression in these progenitors remains unclear. Similarly, and in agreement with the literature, increased levels of Ki67+ER+ cells were observed in TDLUs of postmenopausal as compared to premenopausal women [59, 81].

The present observations have several important implications. Thus, our study indicates that the current view of $\mathrm{K} 8 / 18+$ luminal cells vs. $\mathrm{K} 5 / 14+$ basal/myoepithelial cells as basic biological constituents of normal human breast epithelium and their tumors $[82,83]$ needs to be modified. The finding of $\mathrm{K} 5+\mathrm{K} 14+/-$ progenitors within the luminal layer has important conceptual implications not only for our understanding of normal regeneration. For example, a subset of basal-type breast carcinomas may, as suggested by Lim et al.[3], be better classified as the luminal progenitor subtype. Furthermore, the finding of rare p63+K5+ tumors, such as, for example adenoid cystic carcinoma and syringomatous tumors/low-grade adenosquamous carcinoma of the breast, suggests the existence of a corresponding p63 $+\mathrm{K} 5+$ normal cell type as previously discussed [84-86]. With this conceptual knowledge, we may now approach the question of developmental relationships between the cell types in normal breast epithelium and their counterparts in proliferative breast diseases [87]. It is plausible that the diversity of phenotypic and functional characteristics of breast tumors may emerge from a combination of cell of origin features and specific acquired genetic/epigenetic changes of these cells during tumorigenesis [87-91].

Our model does not fully comply with some of the previously published data. We and others have proposed that $\mathrm{K} 5+$ and/or $\mathrm{K} 14+$ cells are bipotent progenitors in the mammary epithelium [1, 6, 92]. This concept has been based on $\mathrm{K} 5+$ and/or K14+ cells as the least differentiated cells that differentiate toward glandular epithelial or myoepithelial end cells. However, as discussed above, the introduction of p63 as an important biomarker in breast epithelium questions the view of $\mathrm{K} 5+\mathrm{K} 14+/-$ cells as 


\section{Normal Human Breast Epithelium}

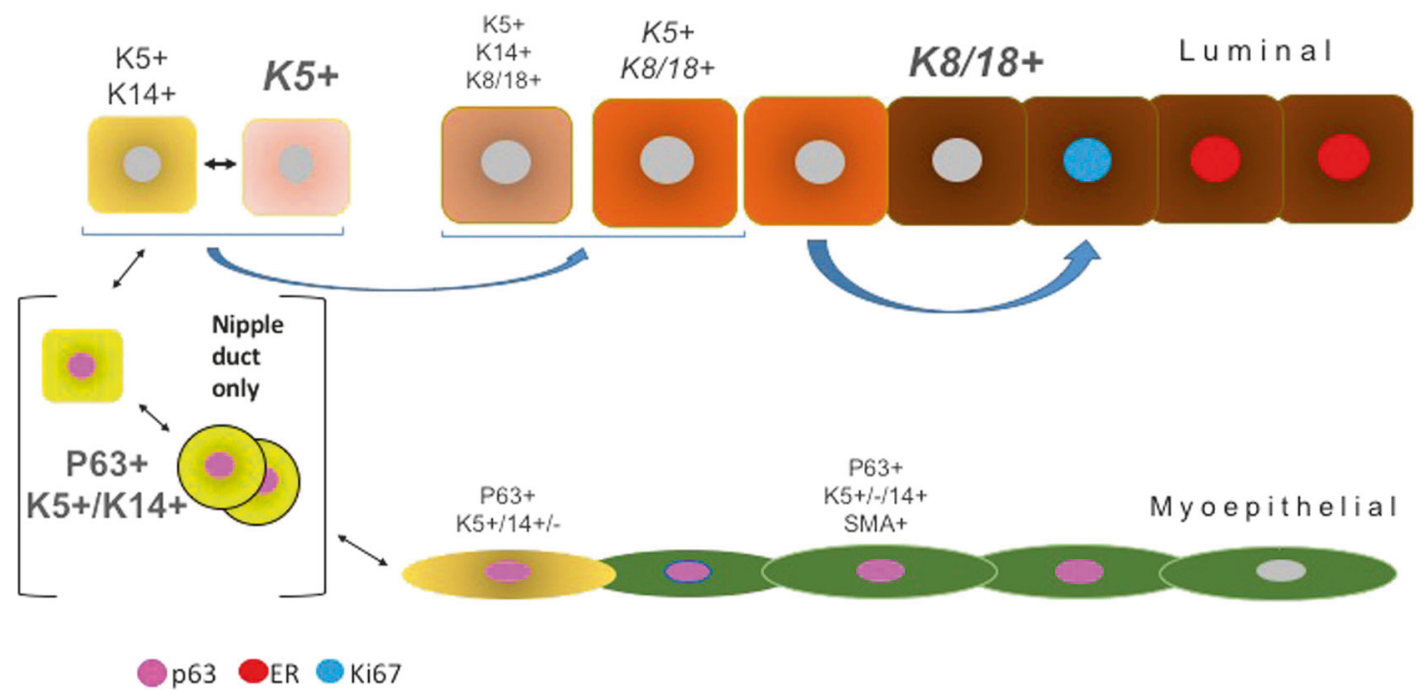

Fig. 8 Tentative working model of the cellular composition of the human breast epithelium, based on p63- and keratin expression pattern. We observed $\mathrm{K} 5+\mathrm{K} 14+/-$ progenitor cells and their progeny

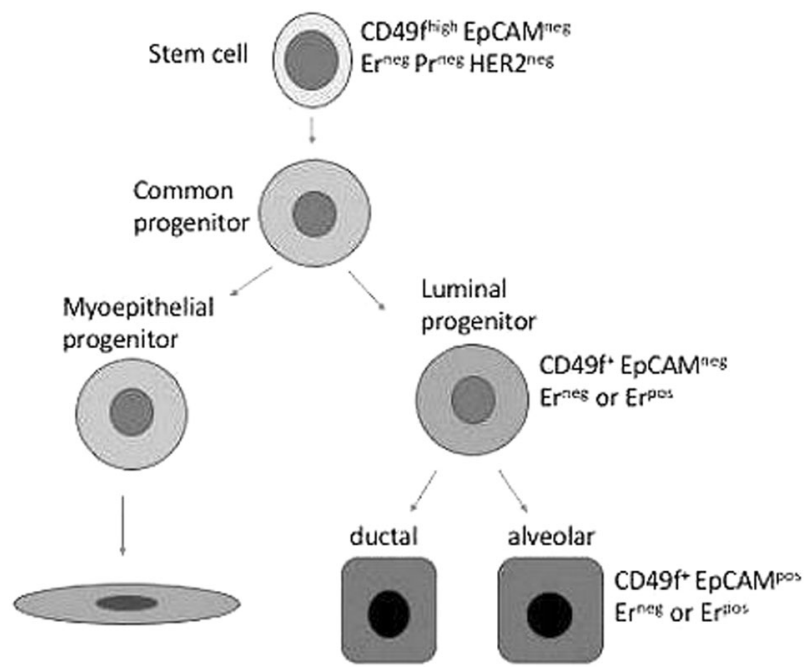

Fig. 9 Hypothetical model of the human breast epithelium, proposed by Lim et al.[3], based on fluorescence-activated cell sorting of human breast epithelial cells with antibodies to surface markers CD49f (alpha6 integrin) and CD326 (EpCAM)

early bipotent progenitors. A different concept of human breast epithelium has also been proposed by Petersen and coworkers [7, 8], who described a ductal stem cell zone characterized by accumulation of $\mathrm{K} 14+\mathrm{K} 19+$ stem cells. Although, we can confirm the existence of $\mathrm{K} 14+\mathrm{K} 19+$ cells in the luminal epithelium (cf. Supplementary Figure 7), we interpret them as intermediary glandular cells identical to $\mathrm{K} 5+\mathrm{K} 8 / 18+$ cells. Finally, one study using a genetic lineage-tracing approach in adult mice [6] suggested the existence of unipotent $\mathrm{K} 14+$ basal and $\mathrm{K} 8 / 18+$ luminal progenitors and noted that $\mathrm{K} 14+$ cells do not contribute to only in luminal cells. Notably, only the nipple ducts contain p63+K5/ $14+$ progenitor cells

the luminal lineage [22]. In the present study, we clearly show that $\mathrm{K} 5+\mathrm{K} 14+/-$ cells are constituents of the human luminal breast epithelium and should therefore be interpreted in the context of luminal cell differentiation [3].

A limitation of this study is that the number of cases studied is relatively small. This is due to the fact that the study and methods used are laborious and time consuming since the quantification is done at the single-cell level on merged and single-channel images and there are no high-throughput techniques available. However, further developments in this area are needed since recent studies have indicated that the cellular "makeup" of the breast epithelium may have an important impact on breast cancer development [3].

In summary, we provide new evidence for the existence of $\mathrm{K} 5+\mathrm{K} 14+/-$ luminal progenitors from which glandular progeny cells evolve. We also demonstrate the presence of a small subpopulation of $\mathrm{p} 63+\mathrm{K} 5 / 14+$ bipotent progenitors confined to the nipple ducts. Moreover, we show that ER expression is associated with differentiated glandular cells and is only rarely observed in progenitors. Based on these findings, we propose a new, modified model of the hierarchical organization of breast ducts and lobules. Future refinements of molecular breast epithelial signatures may provide new important insights into the definition and regulation of stem/progenitor cells in normal and diseased breast tissues.

Acknowledgements The authors wish to dedicate this study to the Professor Werner Franke, a great pioneer in the keratin field, and to the late Professor Karl Lennert and his coworkers, inspiring personalities in the field of pathology. 


\section{Compliance with ethical standards}

Conflict of interest The authors declare that they have no conflict of interest.

Open Access This article is licensed under a Creative Commons Attribution 4.0 International License, which permits use, sharing, adaptation, distribution and reproduction in any medium or format, as long as you give appropriate credit to the original author(s) and the source, provide a link to the Creative Commons license, and indicate if changes were made. The images or other third party material in this article are included in the article's Creative Commons license, unless indicated otherwise in a credit line to the material. If material is not included in the article's Creative Commons license and your intended use is not permitted by statutory regulation or exceeds the permitted use, you will need to obtain permission directly from the copyright holder. To view a copy of this license, visit http://creativecommons. org/licenses/by/4.0/

\section{References}

1. Boecker W, Moll R, Poremba C, Holland R, van Diest PJ, Dervan $\mathrm{P}$, et al. Common adult stem cells in the human breast give rise to glandular and myoepithelial cell lineages: a new cell biological concept. Lab Invest. 2002;82:737-46.

2. Shackleton M, Vaillant F, Simpson KJ, Stingl J, Smyth GK, Asselin-Labat ML, et al. Generation of a functional mammary gland from a single stem cell. Nature. 2006;439:84-8.

3. Lim E, Vaillant F, Wu D, Forrest NC, Pal B, Hart AH, et al. Aberrant luminal progenitors as the candidate target population for basal tumor development in BRCA1 mutation carriers. Nat Med. 2009;15:907-13.

4. Eirew P, Stingl J, Raouf A, Turashvili G, Aparicio S, Emerman JT, et al. A method for quantifying normal human mammary epithelial stem cells with in vivo regenerative ability. Nat Med. 2008;14:1384-9.

5. Clarke RB, Anderson E, Howell A, Potten CS. Regulation of human breast epithelial stem cells. Cell Prolif. 2003;36:45-58.

6. Rios AC, Fu NY, Lindeman GJ, Visvader JE. In situ identification of bipotent stem cells in the mammary gland. Nature. 2014;506:322-7.

7. Gudjonsson T, Villadsen R, Nielsen HL, Ronnov-Jessen L, Bissell MJ, Petersen OW. Isolation, immortalization, and characterization of a human breast epithelial cell line with stem cell properties. Genes Dev. 2002;16:693-706.

8. Villadsen R, Fridriksdottir AJ, Ronnov-Jessen L, Gudjonsson T, Rank F, LaBarge MA, et al. Evidence for a stem cell hierarchy in the adult human breast. J Cell Biol. 2007;177:87-101.

9. Anderson E, Clarke RB. Epithelial stem cells in the mammary gland: casting light into dark corners. Breast Cancer Res. 1999;1:11-3.

10. Badve S, Nakshatri H. Breast-cancer stem cells-beyond semantics. Lancet Oncol. 2012;13:e43-8.

11. Chepko G, Smith GH. Three division-competent, structurallydistinct cell populations contribute to murine mammary epithelial renewal. Tissue Cell. 1997;29:239-53.

12. Diallo R, Schaefer KL, Poremba C, Shivazi N, Willmann V, Buerger $\mathrm{H}$, et al. Monoclonality in normal epithelium and in hyperplastic and neoplastic lesions of the breast. J Pathol. 2001;193:27-32.

13. Dontu G, Al Hajj M, Abdallah WM, Clarke MF, Wicha MS. Stem cells in normal breast development and breast cancer. Cell Prolif. 2003;36:59-72.

14. Dontu G, El Ashry D, Wicha MS. Breast cancer, stem/progenitor cells and the estrogen receptor. Trends Endocrinol Metab. 2004;15:193-7.
15. Hennighausen L, Robinson GW. Think globally, act locally: the making of a mouse mammary gland. Genes Dev. 1998;12:449-55.

16. Howard BA, Gusterson BA. Human breast development. J Mammary Gland Biol Neoplasia. 2000;5:119-37.

17. Kordon EC, Smith GH. An entire functional mammary gland may comprise the progeny from a single cell. Development. 1998;125: 1921-30.

18. Simoes BM, Piva M, Iriondo O, Comaills V, Lopez-Ruiz JA, Zabalza I, et al. Effects of estrogen on the proportion of stem cells in the breast. Breast Cancer Res Treat. 2011;129:23-35.

19. Smalley MJ, Clarke RB. The mammary gland "side population": a putative stem/progenitor cell marker? J Mammary Gland Biol Neoplasia. 2005;10:37-47.

20. Sonnenberg A, Daams H, Van der Valk MA, Hilkens J, Hilgers J. Development of mouse mammary gland: identification of stages in differentiation of luminal and myoepithelial cells using monoclonal antibodies and polyvalent antiserum against keratin. J Histochem. 1986;34:1037-46.

21. Tosoni D, Di Fiore PP, Pece S. Functional purification of human and mouse mammary stem cells. Methods Mol Biol. 2012;916:59-79.

22. Van Keymeulen A, Rocha AS, Ousset M, Beck B, Bouvencourt G, Rock J, et al. Distinct stem cells contribute to mammary gland development and maintenance. Nature. 2011;479:189-93.

23. Clarke RB, Howell A, Potten CS, Anderson E. Dissociation between steroid receptor expression and cell proliferation in the human breast. Cancer Res. 1997;57:4987-91.

24. Stingl J, Eirew P, Ricketson I, Shackleton M, Vaillant F, Choi D, et al. Purification and unique properties of mammary epithelial stem cells. Nature. 2006;439:993-7.

25. Visvader JE, Stingl J. Mammary stem cells and the differentiation hierarchy: current status and perspectives. Genes Dev. 2014;28: 1143-58.

26. Gusterson BA, Ross DT, Heath VJ, Stein T. Basal cytokeratins and their relationship to the cellular origin and functional classification of breast cancer. Breast Cancer Res. 2005;7:143-8.

27. Shehata M, Teschendorff A, Sharp G, Novcic N, Russell IA, Avril $\mathrm{S}$, et al. Phenotypic and functional characterisation of the luminal cell hierarchy of the mammary gland. Breast Cancer Res. 2012;14: R134.

28. Stingl J, Raouf A, Eirew P, Eaves CJ. Deciphering the mammary epithelial cell hierarchy. Cell Cycle. 2006;5:1519-22.

29. Clarke RB, Spence K, Anderson E, Howell A, Okano H, Potten CS. A putative human breast stem cell population is enriched for steroid receptor-positive cells. Dev Biol. 2005;277:443-56.

30. Cheng G, Weihua Z, Warner M, Gustafsson JA. Estrogen receptors ER alpha and ER beta in proliferation in the rodent mammary gland. Proc Natl Acad Sci USA. 2004;101:3739-46.

31. Boecker W, Stenman G, Schroeder T, Schumacher U, Loening T, Stahnke L et al. Multicolor immunofluorescence reveals that p63and/or K5-positive progenitor cells contribute to normal breast epithelium and usual ductal hyperplasia but not to low-grade intraepithelial neoplasia of the breast. Virchows Archiv. 2017;470:493-504.

32. Di Como CJ, Urist MJ, Babayan I, Drobnjak M, Hedvat CV, Teruya-Feldstein J, et al. p63 expression profiles in human normal and tumor tissues. Clin Cancer Res. 2002;8:494-501.

33. Mills AA, Zheng B, Wang XJ, Vogel H, Roop DR, Bradley A. p63 is a p53 homologue required for limb and epidermal morphogenesis. Nature. 1999;398:708-13.

34. Nylander K, Vojtesek B, Nenutil R, Lindgren B, Roos G, Zhanxiang W, et al. Differential expression of p63 isoforms in normal tissues and neoplastic cells. J Pathol. 2002;198:417-27.

35. Reis-Filho JS, Milanezi F, Paredes J, Silva P, Pereira EM, Maeda SA, et al. Novel and classic myoepithelial/stem cell markers in metaplastic carcinomas of the breast. Appl Immunohistochem Mol Morphol. 2003;11:1-8. 
36. Senoo M, Pinto F, Crum CP, McKeon F. p63 Is essential for the proliferative potential of stem cells in stratified epithelia. Cell . 2007;129:523-36.

37. Signoretti S, Waltregny D, Dilks J, Isaac B, Lin D, Garraway L, et al. p63 is a prostate basal cell marker and is required for prostate development. Am J Pathol. 2000;157:1769-75.

38. Yang A, Schweitzer R, Sun D, Kaghad M, Walker N, Bronson RT, et al. p63 is essential for regenerative proliferation in limb, craniofacial and epithelial development. Nature. 1999;398: 714-8.

39. Otterbach F, Bankfalvi A, Bergner S, Decker T, Krech R, Boecker W. Cytokeratin 5/6 immunohistochemistry assists the differential diagnosis of atypical proliferations of the breast. Histopathology. 2000;37:232-40.

40. Altmannsberger M, Dirk T, Droese M, Weber K, Osborn M. Keratin polypeptide distribution in benign and malignant breast tumors: subdivision of ductal carcinomas using monoclonal antibodies. Virchows ArchB Cell Pathol Incl Mol Pathol. 1986;51:265-75.

41. Moll R. Cytokeratins as markers of differentiation in the diagnosis of epithelial tumors. Subcell Biochem. 1998;31205-62:62.

42. Taylor-Papadimitriou J, Lane EB, Neville MC, Daniel CW. Keratin expression in the mammary gland. The Mammary Gland Development, Regulation and Function.. New York, NY and London: Plenum Press; 1987. p. 191-215.

43. Moll R, Divo M, Langbein L. The human keratins: biology and pathology. Histochem Cell Biol. 2008;129:705-33.

44. Moll R, Franke WW, Schiller DL, Geiger B, Krepler R. The catalog of human cytokeratins: patterns of expression in normal epithelia, tumors and cultured cells. Cell. 1982;31:11-24.

45. Nagle RB, Bocker W, Davis JR, Heid HW, Kaufmann M, Lucas DO, et al. Characterization of breast carcinomas by two monoclonal antibodies distinguishing myoepithelial from luminal epithelial cells. J Histochem. 1986;34:869-81.

46. Boecker WJ, Bier B, Freytag G, Broemmelkamp B, Jarasch ED, Edel G, et al. An immunohistochemical study of the breast using antibodies to basal and luminal keratins, alpha-smooth muscle actin, vimentin, collagen IV and laminin. Part II: Epitheliosis and ductal carcinoma in situ. Virchows Arch A. 1992;421:323-30.

47. Gugliotta P, Sapino A, Macri L, Skalli O, Gabbiani G, Bussolati G. Specific demonstration of myoepithelial cells by anti-alpha smooth muscle actin antibody. J Histochem. 1988;36:659-63.

48. Tse GM, Tan PH, Lui PC, Gilks CB, Poon CS, Ma TK, et al. The role of immunohistochemistry for smooth-muscle actin, p63, CD10 and cytokeratin 14 in the differential diagnosis of papillary lesions of the breast. J Clin Pathol. 2007;60:315-20.

49. Kalof AN, Tam D, Beatty B, Cooper K. Immunostaining patterns of myoepithelial cells in breast lesions: a comparison of CD10 and smooth muscle myosin heavy chain. J Clin Pathol. 2004;57: 625-9.

50. Mosunjac MB, Lewis MM, Lawson D, Cohen C. Use of a novel marker, calponin, for myoepithelial cells in fine-needle aspirates of papillary breast lesions. Diagn Cytopathol. 2000;23:151-5.

51. Dabbs DJ, Gown AM. Distribution of calponin and smooth muscle myosin heavy chain in fine-needle aspiration biopsies of the breast. Diagn Cytopathol. 1999;20:203-7.

52. Eddinger TJ, Murphy RA. Developmental changes in actin and myosin heavy chain isoform expression in smooth muscle. Arch Biochem. 1991;284:232-7.

53. Frid MG, Shekhonin BV, Koteliansky VE, Glukhova MA. Phenotypic changes of human smooth muscle cells during development: late expression of heavy caldesmon and calponin. Dev Biol. 1992;153:185-93.

54. Lazard D, Sastre X, Frid MG, Glukhova MA, Thiery JP, Koteliansky VE. Expression of smooth muscle-specific proteins in myoepithelium and stromal myofibroblasts of normal and malignant human breast tissue. Proc Natl Acad Sci USA. 1993;90:999-1003.

55. Moritani S, Kushima R, Sugihara H, Bamba M, Kobayashi TK, Hattori T. Availability of CD10 immunohistochemistry as a marker of breast myoepithelial cells on paraffin sections. Mod Pathol. 2002;15:397-405.

56. Shao W, Brown M. Advances in estrogen receptor biology: prospects for improvements in targeted breast cancer therapy. Breast Cancer Res. 2004;6:39-52.

57. Shaw JA, Udokang K, Mosquera JM, Chauhan H, Jones JL, Walker RA. Oestrogen receptors alpha and beta differ in normal human breast and breast carcinomas. J Pathol. 2002;198: $450-7$.

58. Umekita Y, Souda M, Ohi Y, Rai Y, Sagara Y, Sagara Y, et al. Expression of estrogen receptor alpha and progesterone receptor in normal human breast epithelium. In vivo. 2007;21:535-9.

59. Shoker BS, Jarvis C, Clarke RB, Anderson E, Hewlett J, Davies MP, et al. Estrogen receptor-positive proliferating cells in the normal and precancerous breast. Am J Pathol. 1999;155: 1811-5.

60. Russo J, Ao X, Grill C, Russo IH. Pattern of distribution of cells positive for estrogen receptor alpha and progesterone receptor in relation to proliferating cells in the mammary gland. Breast Cancer Res Treat. 1999;53:217-27.

61. Petersen OW, Hoyer PE, van Deurs B. Frequency and distribution of estrogen receptor-positive cells in normal, nonlactating human breast tissue. Cancer Res. 1987;47:5748-51.

62. Battersby S, Anderson TJ. Proliferative and secretory activity in the pregnant and lactating human breast. Virchows Arch A. 1988;413:189-96.

63. LellÇÎ RJ. In-situ-Bestimmung der Ki-67-Wachstumsfraktion (Ki67-WF) an menschlichen Tumoren (Ergebnisse beim Mammakarzinom). Acta Histochem. 1990;39:109-24.

64. Lima MA, da Silva BB. Expression of Ki-67 and Bcl-2 biomarkers in normal breast tissue from women of reproductive age treated with raloxifene. Arch Gynecol Obstet. 2012;285:223-7.

65. Olsson H, Jernstrom H, Alm P, Kreipe H, Ingvar C, Jonsson PE, et al. Proliferation of the breast epithelium in relation to menstrual cycle phase, hormonal use, and reproductive factors. Breast Cancer Res Treat. 1996;40:187-96.

66. Ross W, Hall PA. Ki67: from antibody to molecule to understanding? J Clin Pathol. 1995;48:M113-M7.

67. Lakhani SR, Ellis IO, Schnitt SJ, Tan PH, van de Vijver MJ. WHO Classification of Tumors of the Breast (4th edition). IARC Lyon: LARC Press; 2012.

68. Buchwalow I, Boecker W, Wolf E, Samoilova V, Tiemann M. Signal amplification in immunohistochemistry: loose-jointed deformable heteropolymeric HRP conjugates vs. linear polymer backbone HRP conjugates. Acta Histochem. 2013;115:587-94.

69. Buchwalow IB, Boecker W. Immunohistochemistry: Basics and Methods. 1 ed. Heidelberg, Dordrecht, London, New York, NY: Springer; 2010.

70. Reis-Filho JS, Schmitt FC. Taking advantage of basic research: p63 is a reliable myoepithelial and stem cell marker. Adv Anat Pathol. 2002;9:280-9.

71. Reisenbichler ES, Ross JR, Hameed O. The clinical use of a P63/ cytokeratin7/18/cytokeratin5/14 antibody cocktail in diagnostic breast pathology. Ann Diagn Pathol. 2014;18:313-8.

72. Yalcin-Ozuysal O, Fiche M, Guitierrez M, Wagner KU, Raffoul W, Brisken C. Antagonistic roles of Notch and p63 in controlling mammary epithelial cell fates. Cell Death Differ. 2010;17: $1600-12$.

73. Buono KD, Robinson GW, Martin C, Shi S, Stanley P, Tanigaki $\mathrm{K}$, et al. The canonical Notch/RBP-J signaling pathway controls the balance of cell lineages in mammary epithelium during pregnancy. Dev Biol. 2006;293:565-80. 
74. Rock JR, Randell SH, Hogan BL. Airway basal stem cells: a perspective on their roles in epithelial homeostasis and remodeling. Dis Models Mech. 2010;3:545-56.

75. Rock JR, Onaitis MW, Rawlins EL, Lu Y, Clark CP, Xue Y, et al. Basal cells as stem cells of the mouse trachea and human airway epithelium. Proc Natl Acad Sci USA. 2009;106:12771-5.

76. Warner SM, Hackett TL, Shaheen F, Hallstrand TS, Kicic A, Stick SM et al. Transcription factor p63 regulates key genes and wound repair in human airway epithelial basal cells. Am J Res Cell Mol Biol. 2013;49:978-88.

77. Daniely Y, Liao G, Dixon D, Linnoila RI, Lori A, Randell SH, et al. Critical role of p63 in the development of a normal esophageal and tracheobronchial epithelium. Am J Physiol Cell Physiol. 2004;287:C171-81.

78. Hong KU, Reynolds SD, Watkins S, Fuchs E, Stripp BR. In vivo differentiation potential of tracheal basal cells: evidence for multipotent and unipotent subpopulations. Am J Physiol Lung Cell Mol Physiol. 2004;286:L643-9.

79. Hackett TL, Shaheen F, Johnson A, Wadsworth S, Pechkovsky DV, Jacoby DB, et al. Characterization of side population cells from human airway epithelium. Stem Cells. 2008;26:2576-85.

80. Ross AJ, Dailey LA, Brighton LE, Devlin RB. Transcriptional profiling of mucociliary differentiation in human airway epithelial cells. Am J Respir Cell Mol Biol. 2007;37:169-85.

81. Clarke RB, Howell A, Anderson E. Estrogen sensitivity of normal human breast tissue in vivo and implanted into athymic nude mice: analysis of the relationship between estrogen-induced proliferation and progesterone receptor expression. Breast Cancer Res Treat. 1997;45:121-33.

82. Sorlie T, Tibshirani R, Parker J, Hastie T, Marron JS, Nobel A, et al. Repeated observation of breast tumor subtypes in independent gene expression data sets. Proc Natl Acad Sci USA. 2003;100:8418-23.

83. Perou CM, Sorlie T, Eisen MB, van de Rijn M, Jeffrey SS, Rees $\mathrm{CA}$, et al. Molecular portraits of human breast tumours. Nature. 2000;406:747-52.
84. Boecker W, Stenman G, Loening T, Andersson MK, Bankfalvi A, von Holstein S, et al. K5/K14-positive cells contribute to salivary gland-like breast tumors with myoepithelial differentiation. Mod Pathol. 2013;26:1086-100.

85. Boecker W, Stenman G, Loening T, Andersson MK, Berg T, Lange A et al. Squamous/epidermoid differentiation in normal breast and salivary gland tissues and their corresponding tumors originate from p63/K5/14-positive progenitor cells. Wirchows Archiv. 2015;466:21-36

86. Boecker W, Stenman G, Loening T, Andersson MK, Sinn HP, Barth $\mathrm{P}$ et al. Differentiation and histogenesis of syringomatous tumour of the nipple and low-grade adenosquamous carcinoma: evidence for a common origin. Histopathology. 2014;65:9-23.

87. Buerger $\mathrm{H}$, Boecker W. New insights into the pathogenesis of in situ carcinomas of the breast by means of comparative genomic hybridization. In: Silverstein M, editor. Ductal carcinoma of the breast. New York, NY: Lippincott Williams \& Wilkins; 2002. p. 67-76.

88. Weigelt B, Horlings HM, Kreike B, Hayes MM, Hauptmann M, Wessels LF, et al. Refinement of breast cancer classification by molecular characterization of histological special types. J Pathol. 2008;216:141-50.

89. Weigelt B, Reis-Filho JS. Molecular profiling currently offers no more than tumour morphology and basic immunohistochemistry. Breast Cancer Res. 2010;12:S5.

90. Buerger H, Otterbach F, Simon R, Schafer KL, Poremba C, Diallo $\mathrm{R}$, et al. Different genetic pathways in the evolution of invasive breast cancer are associated with distinct morphological subtypes. J Pathol. 1999;189:521-6.

91. Going JJ. Ductal-lobar organisation of human breast tissue, its relevance in disease and a research objective: vector mapping of parenchyma in complete breasts (the Astley Cooper project). Breast Cancer Res. 2006;8:107.

92. Dontu G, Abdallah WM, Foley JM, Jackson KW, Clarke MF, Kawamura MJ, et al. In vitro propagation and transcriptional profiling of human mammary stem/progenitor cells. Genes Dev. 2003;17:1253-70. 